\title{
Sustainable feeding systems based on the use of local resources
}

\author{
PP Roggero 1, S Bellon 2, M Rosales 3 \\ 1 Dipartimento di Biotecnologie Agrarie ed Ambientali, Università di Ancona, via Brecce Bianche, 60131 Ancona, \\ Italy; 2INRA-SAD, Ecodéveloppement, Domaine Saint-Paul, Site Agroparc, 84914 Avignon, France \\ ${ }^{3}$ CIPAV (COLCIENCIAS) Centro para la Investigacion en Sistemas Sostenibles de Produccion Agropecuaria, \\ AA20591 Cali, Colombia
}

Summary - Sustainability is a socially constructed concept whose meaning often depends on the context. After defining the feeding system and the meaning that can be attached to the concept of sustainability, its application to existing systems is examined. The attributes of sustainability are derived from an analysis of time-tested systems in Mediterranean and tropical regions. Farm organisation, animal intake and product quality are considered to mean more than mere correspondence between feed requirements and crop production patterns. The rational management of rangeland and forestry systems was taken as an example of organisation and planning of the use of renewable local resources. The multiple use of a specific feed resource and the development of mixed pasture-cropping systems, with possible inclusion of fodder trees and shrubs, were considered as examples of diversification and exploitation of local resources. The integration and fractioning of diverse feed resources and the combination of different activities in a given area, are intended to constitute a global approach to land use aimed at reducing off-farm inputs whilst enhancing natural resources and nutrient recycling. This approach should facilitate the development of mixed and diversified systems, with alternative yield objectives, low environmental impact and reduced economic hazards. Examples are reported on the intercropping of forage, food and fuel sources in the tropics, and for cereal and livestock production in the Mediterranean basin. Flexibility of ruminant production and complementarity between animal species are also described as examples of integration and multiple use of local feed resources. The discussion deals with the possible roles of fodder species and the need to combine several activities into dynamic agricultural systems. Attention is also drawn to the vital links between farmers and the wider rural community through coordinated actions that are appropriate to a mosaic of local conditions.

\section{Introduction}

A major objective, both for research and extension, has often been to increase plant or animal production and use feed resources more effectively. The question of integrating resources into feeding systems is still pending; it implies the organisation of different combinations of herbivores and feeds in management units (livestock farming systems). Therefore, special attention must be given to existing situations in which livestock farmers already use a diversity of resources, and to enhancing system adaptability. In addition, emerging sustainability concerns are challenging both prevailing situations and our ability to assess or suggest alternative feeding systems.

In this paper, the meaning of sustainability that can be attached to tropical and Mediterranean feeding systems is examined starting at the grassroots level and taking examples from time tested farm practices. Farm organisation, animal intake and product quality are considered to mean more than mere correspondence between feed requirements and feed resources.

\section{Feeding systems and sustainability}

A feeding system can be defined as an organisation of the allocation of feed resources to groups of animals for at least one production cycle. As part of the farming system, the feeding system is affected by whatever affects the main system. To analyze feeding systems requires investigations in farm operations where farmers are monitored and interviewed about their practices and behaviour in terms of management, feeding scheme, feed storage and supplementation. The aim is to describe 
the solutions designed and implemented by the livestock farmer year after year and to understand the significance of the observed actions (Guérin et al, 1994; Scoones ,1989).

The feeding systems described in this paper have been analysed using the following steps:

- characterisation of available resources and their feeding value in the various steps of the production cycle;

- identification of possible substitutions and complementarities (opportunity assessment);

- identification of the most appropriate methods to utilize, improve, supplement and cultivate forages, and obtain and renew resources (management).

In this paper, the term resources connotes the effective use of a production factor. For instance, as far as grazing is concerned, a resource is recognized as such when intake actually occurs; otherwise it is considered as a potential resource, e.g. a vegetation or a plant community with its own dynamics. "Local» resources are sources of feed (nutrients) that are easily accessible to the farmer (e.g. forage, crops residues, residues of agro-industrial processes, etc.).

Sustainability is a catchword and an old concept that has been rediscovered in relatively recent times by policy-makers and scientists (Farrington and Nelson, 1991). The numerous attempts to define it ignore the idea that sustainability, like a landscape, is in the eye of the observer. Sustainability may be considered as an additional systems property, that differs from productivity, stability and equitability (Conway ,1987), or conversely as a "package" comprising: viability (economic), reproducibility (see resilience and adaptability), liveability (work aspects) and environmental integrity. However, there is almost general consensus about:

-the unsustainable economic, social and environmental consequences of external-inputoriented agriculture, because it relies on resources being utilized in a way that impedes or restricts the fulfilment of other objectives (Ravnorg, 1992);

-the general directions in which modern farming systems can move to become more sustainable. This economically and environmentally viable alternative includes a wide spectrum of farming systems where a more efficient and rational use of labour, knowledge, and management skills replace off- farm inputs (Pretty and Howes, 1993). Sustainable agriculture involves longer time frames, requires more information than inputs, depends more on natural processes, represents more a craft than a recipe or formula, and often requires cooperation beyond the individual farm (Röling, 1992).

$A$ review of the feeding systems used in warm climates suggested that the application of the sustainability concept to a feeding system based on local resources is justified when it includes:

- organisation and planning of the local resources taking into account their renewal in space and time;

- use of the biodiversity and diversification of the resources;

- integration and multiple use of the resources; - adaptation and development of security measures.

These practices are closely related to each other, and their application is the key to many sustainable feeding systems in warm climate areas. For a better understanding of what sustainable feeding systems are, practical examples will be given of their application in feeding systems used in tropical and Mediterranean areas.

\section{Organisation and planning}

In livestock farming, the farmer's production plans determine strategies to organize various feed resources in time and space for the different groups of animals, taking into account their renewal and evolution. Depending on the farmer's financial logic, the guiding principle of "organisation and planning" can be aimed at "immediate optimalisation" or at "long term" planning. In the latter case, the management skills fixed by the farmers and the choices he makes are not based on the immediate financial situation, and leave room for a variety of subsequent decisions (Attonaty and Soler, 1991). The application of the concept of "organisation and planning" to feeding systems is closely linked to the farming system, and it is suitable when it is vital to system sustainability. Available resources are allocated according to the production objectives and the role assigned to each feed. The farm organisation is the result of the farmer's production strategy. It may become more complex when farmers' objectives are varied, or when the environmental constraints 
impose a diversification of the feed sources to secure the feeding system during critical periods.

In the Mediterranean basin, the diversity of rangelands (grass, shrubs and woodlands) and their combination with other cultivated or "external» resources, calls for a complex organisation, i.e. strategies implemented by livestock farmers to match heterogeneous, irregular and evolutionary fodder resources. The Mediterranean feeding systems that are based on rangelands, are often located in regions marked by strong environmental and/or socio-economic constraints. In Italy, for instance, $90 \%$ of the grazing sheep and goat are reared in the central and southern regions and on the islands (ISTAT, 1994).

The following example illustrates how a year-round combination of resources can meet the needs of an animal production schedule based on two lambing periods with a good level of animal productivity (figure 1). The lambing period is planned to schedule lactation during the period of high grass growth. In this period ewes are stockfed on hay and grain inside a shed while the rest of the flock grazes on the rangelands. At the time of mating (1 month) and lactation (3 months), animals are fed on cultivated pastures and improved rangelands in a rotational grazing system, and are divided into two or three batches. Both flock maintenance periods (summer and winter) are spent on rangelands, with feed supplementation only, if necessary, at the end of each period when the animals due to lamb are segregated. The combined management of crops, woodlands and forest resources ("organisation") may result in the assignment of multiple functions to the trees and shrubs, which are solicited to bridge the "feeding gaps" of the pasture between seasons ("connections") thus securing the feeding system and reducing investments (Guérin and Bellon, 1989). Practical examples of these livestock systems are reported for the mountain regions of southern France, where sheep, goats and cattle are also assigned multiple functions i.e. forest preservation from fire and degradation, and maintenance of human activities in poor territories, through a rational plan to exploit natural and cultivated feed resources (INRA Ecodéveloppement and CERPAM, 1990; Bellon and Guérin, 1992; Bellon, 1995).

In the tropics, a good example of this is the highly organized "coppice manipulation system" that has been proposed for the Brazilian Caatinga (Hardesty, 1988). Caatinga woodland covers about $10 \%$ of Brazil. It is an arid region characterized by low rainfall and poor soils. The vegetation ranges from open parklands with a sparse succulent and cactus understory to dense, closed stands with almost no understory. It is managed under a bush fallow system. The land is cleared by hand, the vegetation is burnt, and crops are planted. After many years of cropping, productivity decreases, and the fields are abandoned. During the dry season, livestock (cattle, sheep and goats) are forced to survive on the leaf litter of the unmanaged Caatinga. The clearings are difficult to maintain because Caatinga species regenerate from seed and by coppice.

In the "coppice manipulation system", coppicing is reduced by changing the season when trees are cut or by repeatedly removing the coppice growth from the stump.

Different species respond in different ways to these methods of management. Some species that do not normally produce usable forage are palatable as coppice growth; other species, whose leaves are not consumed until they fall from the tree, are browsed as green coppice. Coppice growth has the ability to retain green foliage longer into the dry season than intact trees of the same species. The result is a more favourable distribution of the forage production and quality. The system requires careful planning of what plants to cut, where and when in order to maintain the species composition and the supply of adequate and sufficient foliage during the dry season.

The concept of organisation and planning also applies to local resource renewal as part of grazing management. In the Mediterranean areas the cultivated self-reseeding annuals are protected from grazing in the spring of the establishment year in order to secure natural re-establishment in the following years (Bullitta et al, 1989; Ewing, 1989; Sulas et al, 1993). In Sardinia and other pastoral areas of southern Italy, the rangeland grazing management is planned to give suckling and lactating dairy ewes access to the best pasture as first; they are replaced by the dry animals and/or beef cattle as their milk production decreases. In these areas, the feeding system is designed to provide as much feed as possible from 


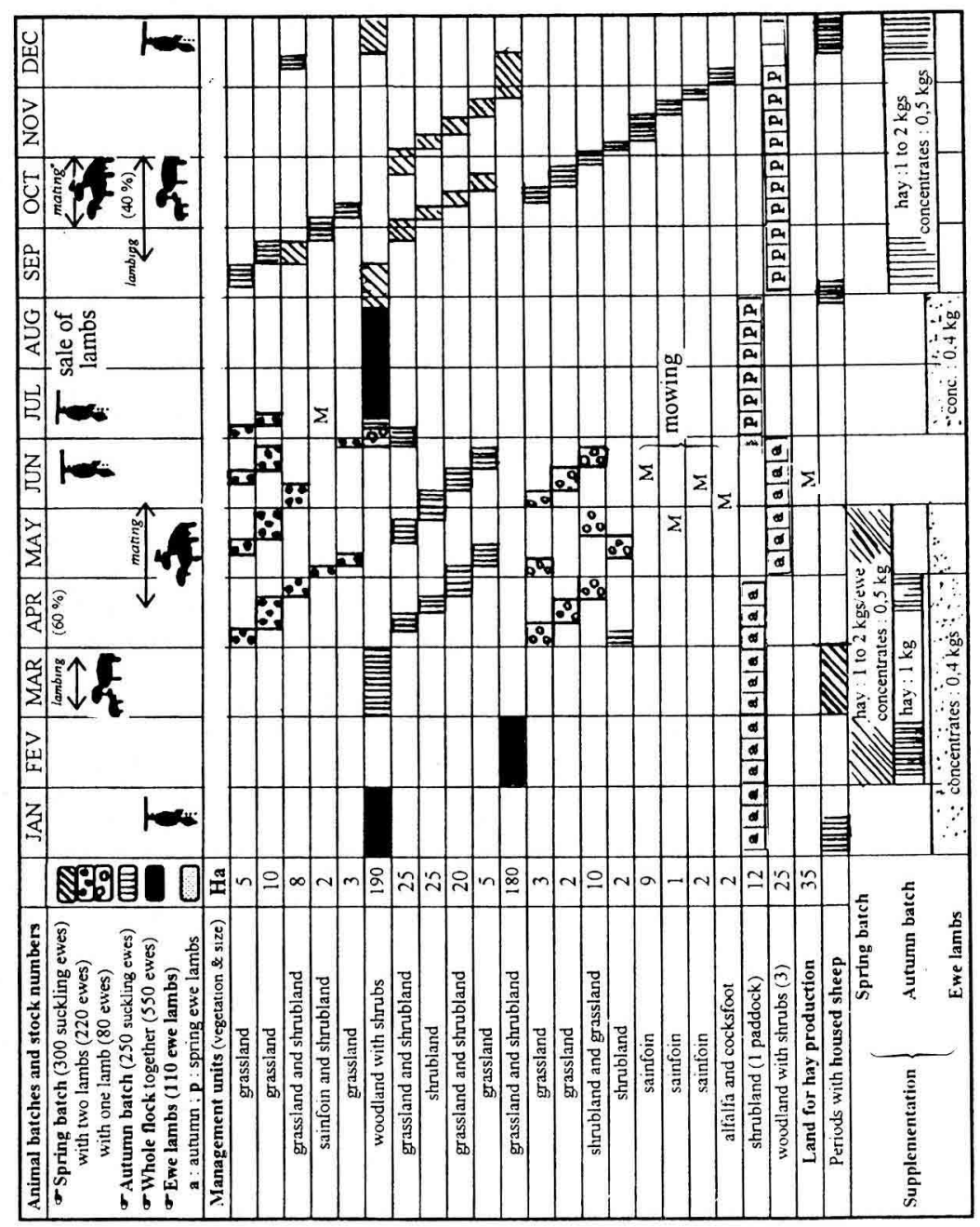

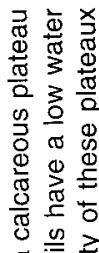

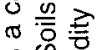
유

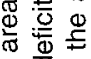
는 흔 $\div$

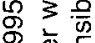
흥 용 की क 몸 뭉 $\frac{0}{0}$ ป ब. 늘 흥 बึ 든 웜 蓑这 号管 응ㅎㅁ N - D 实高

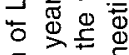
을 퉁ํำ 元 융응 흔

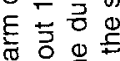
๘ 웡ㅁ음 这的焉

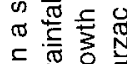
홍 능 곤 ठิ

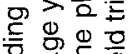
융

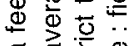
징 ธㄷํ 凹 贾专定 年交会 票 Оิ - E 융 인 홍ㅇㅇ흠 
rangeland grazing and to reduce off-farm feed supplementation (Casu et al, 1989; Rubino et al, 1995). In some areas, where beef cattle are reared in the rangelands, the only external inputs are alkaline phosphate fertilizers (to buffer the soil acidity) and a part-time labour force. The farmer engages in extra-agricultural activities when the farm size is too small to guarantee an acceptable income.

When an altitude gradient is available, rangeland grazing can be planned so that animals exploit the early autumn production of the highlands and the late autumn production of the lowlands in the winter. Annual forage crops (e.g. oats, Italian ryegrass or mixtures of annual legumes and grasses) are cultivated in the autumn on small arable surfaces to provide winter grazing and one hay cut in May (Caredda et al, 1992).

\section{Diversification and use of local biodiversity}

When applied to the feeding system, diversification is the key to reduce risk increasing system stability. It is a concept that can be applied at different levels: diet composition, feed resources and their management, animal species and breeds, crop cultivation, biodiversity of natural and cultivated pastures, etc. (Meuret et al, 1995). It calls for complementarity in terms of feed quality, production pattern of the various resources, labour demand, and farm capital allocation (machinery, buildings, irrigation facilities, etc.). The diverse production, quality and palatability pattern of various forage resources (rangelands, woodlands, cultivated species and varieties) can be exploited through the combination in space and time of complementary resources, thus reducing supplementation with stored feed (Cereti and Talamucci, 1991). When hypothetical combinations are to be translated into practice, the possible effects of different combinations of feeds on the farm organisation, animal intake and products quality, need to be studied. For example, in the Mediterranean area, fodder trees and shrubs have been proposed by many authors as a strategic resources that can provide green forage during "critical periods". Nevertheless the cultivation of forage trees and shrubs has only been developed on an experimental basis because of high plantation costs. Similarly, many species that proved to be very productive in the semi-arid Mediterranean areas (e.g. valuable perennial grasses, including the so-called warm-season grasses) are not popular because of the high price and relatively poor availability of seed to the farmers and in some cases because of the lack of extensive on-farm testing.

In the humid savannas of South America, Africa and Asia, emphasis has been placed on increasing biomass through the introduction of more productive grasses and in association with $\mathrm{N}$-fixing legumes. Soils in this region are characterized by low fertility and high acidity, requiring highly adapted fodder species. Compared to the traditional management, a system of crop-pasture practices (upland rice, cassava, maize - Andropogon gayanus, Centrosema acutifolium), can boost the production substantially (projected estimates suggest a $44 \%$ increase in rice production of $44 \%$, and a 15 -fold increase in livestock weight gain per hectare) (WRI, 1990).

In the tropical agroforestry systems, despite the fact that the list of trees and shrubs with potential use for fodder is vast, many feeding systems depend on a small number of species. The danger of over-dependence on few species has been brought to light by the severe psyllid attack on Leucaena sp., (Moog and Sison, 1986; NFTA, 1987; Moog, 1992a), and the disappearance of some valuable fodder species (Terminalia avicennioides) in Niger, due to the over-utilisation of Gliricidia sepium (Baumer, 1992).

Shrubs and trees, occasionally, can contribute to the sustainability of the system. The South American savannas (Cerrados in Brazil, Llanos in Colombia and Venezuela) however are not treeless plains; they have areas of shrubby vegetation and islands of forests of medium size trees that form closed canopies (there are Indian tribes in the region that can recognize some fifteen formations that vary according to the amount of shrub or tree cover, the presence of water, and the location with respect to rivers and hills). These natural formations are also known to be a reservoir for birds and mammals like anteaters, wolves, deer, armadillos, and peccaries (Gradwohl and Greenberg, 1988). The first census recently completed in Venezuela's western Llanos determined the existence of 49 plant species in the lowland gallery forests (Stergios, 1995). To improve the sustainability of a system for the 
savannah, local resources should be included as an integral part. Promising fodder plants from these formations should be studied. A resource largely ignored and even under threat are the paims of the Astrocayum, Attale and Mauritia genus. They could be integrated in an agroforestry system to provide oil and byproducts or just fruit for pigs and cattle.

The concept of diversification can be also applied to the multiple use of a given feed resource (Meuret et al, 1995). The spring production curve of a Mediterranean annual grass-based pasture can be smoothed by increasing the grazing pressure on areas while preserving other fields from grazing to provide the accumulation of hay or silage, or to produce grain or forage seeds (Bullitta et al, 1992; Roggero et al, 1993). Diversification is also applicable to the whole farming system. In the irrigated lowlands of Sardinia, farmers are gradually associating dairy sheep farming with other agricultural activities (open field horticulture, cereal grains), thus improving the labour force efficiency and income from the whole farming system.

\section{Integration and multiple use of the local resources}

The feeding system, as a sub-system of the animal production and farming systems, cannot be considered as independent of them, but the characteristic of «being part of» increases its sustainability. Feeding systems can make use of outputs from the main system and generate outputs of use to the main system. The concept of crop-stock integration is a major issue at UICN (World Conservation Union), UNEP (United Nations Environment Program) and the WWF (World Wildlife Fund), when speaking about "sustainable living", as it is an appropriate way to recycle nutrients that would become pollutants if crops and livestock were separated (UICN-UNEP-WWF, 1991). In this context, an integrated system could be defined as a global approach to land use for agricultural production, with an attempt to reduce external inputs (auxiliary energy, chemicals) while improving the use of natural resources and regulatory processes (e.g. nutrient recycling through the use of trees). This would lead to mixed and diversified systems, which could result in moderate yield objectives, lower environmental impact and reduced economic hazards.

The quality of the feed resources can benefit from the integration of feeds that are complementary (e.g. mixture of grass and legumes). Each feed source can play a different role in the feeding system, in relation to its nutritional value when it is actually made available to the animals. Winter cereals, for instance, represent a balanced feed when grazed in the vegetative stage, while protein supplementation is required when it is eaten as grain, hay or stubble. In nature, livestock feeding is achieved through the combination of several elements, provided by the natural flora diversity in space and time, animal selectivity and movement. In the cartificial» livestock feeding systems, the integration of more than one feed resource is essential to achieve a satisfactory feed quality and hence to make a feeding system efficient.

The concept of integration can also be applied when combining activities to form integrated systems that avoid concentration on lands with higher potentials and abandonment of the rest of a territory. In the South of France, as part of the "extensification" concept, when a farmer retires, neighbouring farmers take over his land and thereby increase their own farm land. With a new organisation in land use, priority for new lands often goes to more productive areas, e.g. for hay production. Conversely, the included rangelands may be abandoned. Therefore, in the South of France, attention has been paid to pastoral land improvement (fencing, watering, etc.) in order to increase labour productivity and maintain a long term grazing capacity.

An intensive livestock production system developed in Colombia, that has been proposed as a sustainable solution for the humid tropics, is an example of integration and multiple use of local resources (figure 2). The system is based on the use of sugar cane (planted at high density) intercropped with multipurpose trees and water plants, as sources of biomass to provide feed for different animal species and food and fuel for human consumption. This system is composed of several viz. biomass, monogastric, ruminant and fuel sub-systems that can be introduced separately or integrated. It is directed at resource-poor farmers but has been adapted for use on a commercial scale (Preston and Murgueitio, 1992a). In this model, after removal of the tops, the sugar cane is separated into 


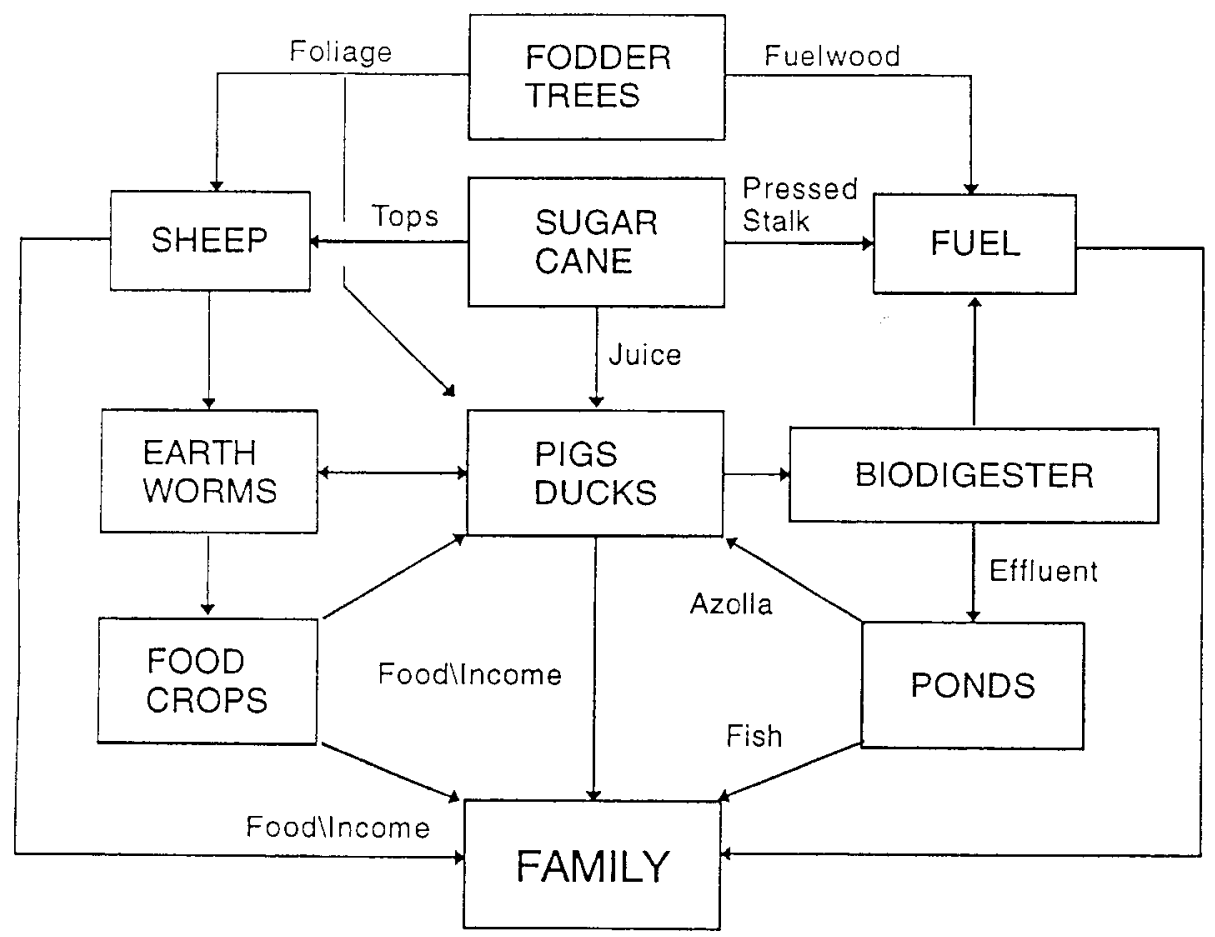

Figure 2 - Integrated farming system based on high biomass production. The diagram illustrates the principle of integration of the feeding system within a farming system. Fractionation of sugar cane and fodder trees into their main components, permits a maximum resource utilisation according to the principle of multiple use of resources.

juice and bagasse in a three-roller mill. The juice is used as a replacement for cereals. It is combined with the fresh water fern Azolla filiculoides and whole soybean grain, and fed to pigs and ducks. Local fodder tree species i.e. Gliricidia sepium, Trichanthera gigantea or Erythrina fusca, are used; the choice is based on their capacity to adapt to local conditions (Preston, 1992). The tree foliage is harvested and the leaves are used as a source of protein to supplement the sugar cane tops for feeding sheep. The animals are confined so that their excreta can be collected through the ponds and plastic-bag biogas digesters and recycled to provide fuel. Pressed stalks and stems are also used as fuel. In this integrated system, waste products are kept to a minimum, and the local resources are efficiently used. Fuel production is an added benefit of integration for the family and the environment (Preston and
Murgueitio, 1992b). On the other hand, the fractionation of the sugar cane into tops, juice and bagasse and of the trees into leaves and stems is an example of multiple and efficient use of the resources. Tops, when adequately supplemented, will support high liveweight gains in ruminants. Feeding whole cane will have the same effect, but the possibility of feeding monogastrics with the same resource is lost (Meija et al, 1991).

There are numerous examples of integrated systems for the tropics where grazing is integrated into a cropping system. Several approaches to involve both crops and grazing animals are briefly considered below. The food-feed intercropping system is been undertaken in Philippines and Thailand. This system provides a viable method for providing food, cash and/or income for humans and as well as feed for animals. The strategy is to 
integrate within the rice cropping pattern (intercropping and relay cropping) other feed producing crops and forage crops without reducing the area of land used. So while the food crop, usually rice (other crops used with the aim of increasing the production of animal feeds include cowpea, maize, groundnut, pigeon pea, sorghum and sweet potato), is grown during the wet season, forage production, grasses and feed legumes, from intercropping provides feed throughout the dry season. The supply of feeds for animals can be further increased when a second crop is planted into the first before harvest (relay cropping). Another approach is the three strata forage system, for dryland farming areas, which is been developed in Bali. The system involves grasses and ground legumes (first stratum), shrub legumes (second stratum) and fodder trees (third stratum). When compared with a non strata system, the three strata forage system increased forage and fuelwood production, liveweight gain, stocking rates and reduced soil erosion. Integrating grazing ruminants (mainly small ruminants) with tree crops such as coconuts, oil palm and rubber is another important system, common in humid and in sub-humid regions of the tropics, especially in Asia (although it has not been adequately exploited). A specific example of this integration concerns the case study of an oil palm state in Malaysia. In this case, the state allocated a portion of the plantation to the workers for grazing their animals. A comparison between grazed and not grazed areas (for four years) showed that there was a significant increase of fresh fruit bunches in the grazed areas (Devendra, 1991). The system can be enhanced by the presence of a legume cover to have all the complementary advantages of an agro-forestry system; forage production, supply of fuelwood and tree products, improvement of soil fertility and maintenance of permanent soil cover (Devendra, 1993).

An example of crop-stock integration can be seen in the combination of grain cereals and ruminant livestock. In the Mediterranean basin, oats, or barley in the drier areas, provide good quality forage during tillering, and the stubble can be efficiently grazed or fed to confined animals when supplemented with proteic feeds (e.g. Guessous et al, 1989). These systems are usually located in the lowlands (400-500 $\mathrm{mm}$ in 4-8 months): rangelands are confined to the non-arable soils and are very low in quality and productivity. while the arable soils are periodically cultivated with cereals and forage crops. Originally, this system was based on transhumance, the flocks being driven by the shepherds from mountains that are too cold in the winter to the lowlands to graze the cereals during winter (i.e. lambing and lactating season) and back to the mountain rangelands in the summer. Nowadays, even where long distance $<100$ $\mathrm{km}$ ) transhumance has disappeared, dairy sheep and cereal production are still combined. On farms where cereal and livestock are not combined, lands with stubble (summer) or the grass (winter) are often rented to shepherds. In the mixed farms, the winter growth potential and forage quality of local landraces of oats and barley is exploited by grazing up to midFebruary, with almost no negative effects on grain yield (Bullitta and Spanu, 1977). In the rainfed lowlands of Sardinia, the dairy sheep production cycle is adjusted to the annual cereal forage production pattern. The main lambing season occurs in November, and more scattered lambing (ewe-lambs and ewes that were not pregnant in the late spring mating season) occurs from end January to March. In spring, some parts of the cultivated fields are exclosed to animals in order to produce grain and/or hay; the whole flock is confined on the remaining cultivated fields or in the rangelands, where a high grazing pressure fits in with the spring flush. In the summer, the stubble is grazed by early-pregnant ewes. The flexible and multiple use of the oats and barley (grazing, hay, sometimes silage, grain, byproducts) is a way to achieve consistent labour production objectives and allows the farmer to make a decision on the type of management at the right time, in relation to the available feed stocks, the weather at hay-making, the rangeland production and the grain price. Crop rotation is often based on the succession of winter cereals and the "grazed-ploughedfallow", fallow that is often represented by palatable weeds.

In arid Mediterranean areas (e.g. The Middle East and North African regions with $<350 \mathrm{~mm}$ annual rainfall), the cereal system is often based on barley and weed-fallow. The integration of a hard-seed annual selfreseeding legumes in the fallow year (ley farming system), if properly managed (e.g. shallow ploughing), was recognized to be 
beneficial to livestock and grain production and to soil fertility (Cocks and Gintzburger, 1993). The hard seed mechanism retards the germination of the ripe seeds over the years, and guarantees the natural development of a legume "seed-bank" in the soil that allows the germination of a sufficient number of seedlings during the fallow year. The multiple uses of forage legumes in the livestock farming systems have been discussed by many authors (e.g. Besse and Sebillotte, 1986; Robson, 1990; Bellon, 1993), and as the ley farming system is reviewed, improved and adjusted to local conditions, it is becoming more flexible (Reeves and Ewing, 1993).

The balance between crop and livestock in these systems is dynamic since it predicates on erratic seasonal rainfall and cereal pricing (i.e. government subsidies, stock fluctuations). Rangelands and woodlands usually represent a secondary feed resource, but their role is only important in the autumn, when the cereal fields are freshly sown and cannot be grazed (Sulas et al, 1994).

Although cereal-sheep mixed farming is diminishing in rich areas, it still exists in areas of extensive cultivation such as Aragon (Spain), Provence (France), southern Italy and Mediterranean islands. Cattle is even increasing in Alentejo (Portugal) where cereal farming systems are dominant. The question is whether mixed farming should evolve towards the specialized extensive livestock system or, conversely, if it should lead to a functional balance for various objectives: income stability, number of jobs to maintain on the farm, etc. However, mixed production systems must be compatible with increased labour productivity. This entails a limited extension of such systems in the Mediterranean Europe, since few farms have sufficient land to develop several activities (Pluvinage, 1995), except if land utilisation patterns are consistently modified and/or are suitable for complementary uses (e.g. sylvopastoral systems, new functions assigned to farming, etc.). In the large farm units of the lowlands of Provence (France), the problem to achieve a sufficient overall gross margin at farm level, in order to pay employees' wages or family-labour led to the decision to maintain animal productions in order to exploit the less intensified farm areas or the crop by-products (aftermath, stubble, etc.).

Another example of integration is that between animal species whose feed requirements are complementary. In the Mediterranean area the dairy sheep are often integrated with free-ranging beef cattle, thus contributing to exploiting low quality and woody pastures and increasing the labour force efficiency (Casu et al, 1989).

\section{Adaptation and development of security devices}

Adaptation to local environmental conditions is part of the concept of physical sustainability (Spedding, 1995). It can be applied to the animal species and breeds, forage species and varieties and to the socio-economic context. When forage species and varieties are concerned, adaptation means productivity and persistence, but also matching the utilisation pattern with the feeding calendar, suitability with flexible management and the achievement of specific resources (Meuret, 1993). In the Mediterranean area, local ecotypes have often proven to be much more productive and persistent than commercial varieties (e.g. Franca et al, 1995). Farmers' criteria for choosing species and varieties may well be different from those of the technicians; they often prefer to multiply local ecotypes and landraces rather than to buy costly certified seed that is not always suitable to the local conditions (Roggero et al, 1990)

The African palm (Elaeis guineensis, Jack.) is an interesting and important alternative for the development of integrated livestock production systems based on crops, and a good illustration of the principles of adaptation and flexibility. This example is also closely related to the concept of multiple use. The system can be adapted to different conditions and is suitable for all size producers. It offers different possibilities that can be combined to various extent depending on situations (Ocampo, 1995):

1. Commercial production. All the fruit is used to extract and refine the oil. African hairsheep are used to control weeds and do not affect palm oil production. Mud and effluent, when the oil content is near $8-10 \%$, can also be used as animal feed

2. Rejected truit. 20 to $30 \%$ of the harvested fruit for oil production is rejected because of its low quality (unripe and recent plantings fruits) and used for animal feeding. Using rejected 
fruits as animal feed enables the system to support a higher stocking rate.

3 . Inter cropping with fodder trees. The interrow area is used to cultivate fodder trees that provide proteins and contribute to increasing soil nitrogen content.

4. Palm oil for livestock feeding. Up to $30 \%$ of the crude oil can be used in animal feed, thus allowing for an increase in the number and types of animals (ruminants and monogastrics). This provides an alternative to the producer when the market price for palm oil is low. Livestock thus produced can cost less than in systems based on grain feeding.

5. Reduced crop density and additional crops. When the microclimate is favourable to crop production, the diversification of the cropping system reduces dependence on the palm oil market. The system involves $20-30 \%$ of the crop for animal feeding and additional crops such as fruit crops (e.g. lemon, tangerine, orange, etc.) cowpea, aromatic essences, cassava, sugar cane, chili pepper, cocoa, fodder trees and bananas.

6. Integrated system. In this case the palm crop is not intended for oil extraction, but as a strategic base of the productive system. The fruit is produced as animal feed, and all the elements described previously are integrated in a system similar to the high biomass production system described above.

Thanks to its capacity of adaptation and flexibility, the palm system can produce mainly for oil or for livestock, depending on the current economic trend (Ocampo, 1995).

This type of security is an essential part of sustainable feeding systems: apart from "cores", globally stable and controlled, other resources are "buffers" for certain periods during which forage availability fluctuates. These periods are secured by "regulation" and "connection" practices (Guérin and Bellon, 1989).

Regulation practices are designed to alleviate unexpected production fluctuations. Two main types of regulations can be identified: (i) those involving biological processes, for instance the mobilisation and constitution of animal body reserves, that need sufficient foresight and therefore a planning capacity; (ii) those involving more direct interventions on flows, for instance a change in the use of a plot during the year (grazing/hay making), supplementary feed, flexibility in livestock movement and stocking rates. They call for rapid appraisals and answers, i.e. adaptability.

"Connections" are ensured through interseason crop shortage compensation to deal with low forage availability at season's end. This may occur when resources become available after the expected date, especially during transition periods (e.g. winter to early spring or summer to autumn in the Mediterranean region). One way to cope with this gap would be to allow animals into woodlands late in the summer on lands that had been scheduled for use in winter.

\section{Perspectives of sustainable feeding systems in warm climate regions}

\section{Towards a sustainable feeding system as an alternative to tropical deforestation}

The tropical rainforests of Brazil, Colombia, Peru, Indonesia, peninsular Malaysia, Philippines, Thailand, Vietnam, Kenya, Madagascar, Uganda, West Africa and Central America are under continuous pressure from uncontrolled slash-and-burn shifting cultivation, logging and cattle ranching. To protect the remaining forests, a change in national policies is required to discourage settlements, wealthy investors and corporations; the already cleared lands should be transformed into buffer zones. For these zones, all future livestock production system should reflect the principles set out in this paper. It should be fully integrated with crops, trees and other animal species to maximize the use of local resources and minimize waste production; it should have the capacity to adapt, to be flexible and to cope with economic and ecological constraints; and it should have a high degree of organisation and planning of sustainable long term actions to allow such a system to exploit the local biodiversity of plant and animal species. There are increasing reports in literature on the evaluation of fodder resources (shrubs and trees) from these ecosystems: 16 species from the Philippines, (Moog, 1992b); 45 from Costa Rica, 40 from Guatemala, (Benavides, 1994); 20 from Colombia, (Rosales et al, 1992) just to mention a few. Given the diversity of fodder trees, there is an urgent need to study and to recommend promising species, both in terms of plant productivity and nutritional value, for specific agro-ecological environments and animal production systems. 


\section{Evolution of sustainable feeding systems in the Mediterranean basin}

In the past, complementarity between Mediterranean lowlands and highlands was enhanced through transhumance and helped to meet the consumption needs of a dense rural population. In addition, rangelands were the basis of fertility transfers towards cultivated areas based on a two- or three-course rotation. From the early $X X$ th century, the development of transport facilities and market economies opened the way to regional differentiation and marginalisation of the hinterland (Jarrige, 1979). The EU agricultural policy is now reconsidering the public support to production, and some leading segments of public opinion underline the negative effects of certain farmers' practices and of territorial specialisation: artificialisation, concentration (with consequences on animal welfare) and pollution of productive areas on the one hand and, on the other, the abandoning of large parts of the rural countryside, with negative effects such as landscape deterioration, reduction of regional biodiversity and increased fire hazards in the Mediterranean region. The primary role of the livestock producer's activity, therefore, should be integrated with other activities that are more consistent with the socio-economic context, with priority being given to achieving an acceptable quality of life for the farmer and his family. On vacant rural areas, the hinterland is facing new challenges and uses; rangelands are being assigned new social values (reservoir for rare species and support for biodiversity, recreation facilities, etc.) and new functions are being assigned to livestock producers (Hubert et al, 1995).

Rangelands, however, are still being utilized for traditional animal productions (i.e. milk, cheese, meat, beef cattle), particularly in the southern part of the Mediterranean basin. These areas can offer opportunities for production systems designed to use diversified territories, all the while organizing interfaces between the feed resources and the flock. The overall objective is to elaborate a sustainable production project that depends more on internal system flexibility than on external factors (Meuret et al, 1995).

The intensification of animal production systems, especially in south Mediterranean areas (e.g. through irrigation), can increase the interseasonal fluctuations of production, and hence the need for costly stability devices like feed storage, supplementation etc. (Delgado, 1992). This is particularly true for farming systems based on annual crops and for the double cropping system (e.g. winter cerealbased forage mixture + corn/sorghum) that is developing in many irrigated lowlands. This is also the guiding principle of a zero-grazing system named "unifeed" that is being developed for dairy sheep and goats. It has proven to be as an efficient feeding system per se, but much less efficient than a system based on the grazing of perennial forage crops (Molle et al, 1994). The improvement of the grazed/supplementary feed ratio appears relevant to the sustainability of intensive Mediterranean lowland systems as the climate allows grazing almost all year round, thus improving animal welfare, and product quality (Pirisi et al., 1994), and minimizing costs, environmental impact and power needs.

\section{Conclusive remarks}

The attributes of sustainability have to be applied to real farming situations, with thought to both the historical perspective (e.g. pastoral systems that exist since biblical times) and to the current evolution of agriculture, with its new paradigms: from "productivity" to "sustainability". In this context there is a clear need for greater use of «local» resources: identification of new utilisation patterns, integration, combinations to fit the feeding calendar, improved labour productivity, and downstream thereof, system "viability".

The Mediterranean feeding systems and related livestock farming systems are facing new challenges that overlap or substitute the «traditional» ones: unreliable market for products and production factors (e.g. seed), environmental concerns (fire hazards, wildlife and vegetation preservation, soil conservation, pollution of water tables, subsidies for biological agriculture), urban society demands (product quality, amenities, peri-urban dwelling).The development of a feeding system must take into account the farmer's knowledge and the society's aspiration that are parts of the models to design (Jean, 1995). Many practices and systems that are sometimes considered obsolescent can be reassessed in the light of current technology and new paradigms, with a view to also improving 
labour productivity and other attributes. To face these challenges, the systems and multidisciplinary approach appears as an effective way to translate new technologies into practice.

It is difficult to forecast what the conditions of animal production, for both tropical and Mediterranean regions, will be in the future. A useful target, however, can be outlined using the attributes of the sustainable animal production systems reported by Spedding (1995). As far as feeding systems are concerned, the principles highlighted here are relevant to achieving sustainability. The examples shown give evidence that by applying these principles, animal production objectives could be achieved in a more "sustainable» way in warm climate countries.

\section{Literature cited}

Attonaty JM, Soler LG (1991) Renewing strategic decision-making aids. Proc Meet New strategies at the farm level, REAE, 18, 423-442

Baumer M (1992) Trees as browse and to support animal production. In: Legume trees and other todder trees as protein source for livestock, FAO Animal Production and Health Paper (Speedy A, Pugliese $P$, eds) $102,1-10$

Bellon S, Guérin G (1992) Old holm oak coppices... new sylvopastoral practices. Vegetatio 99-100, 307-316

Bellon S (1993) Mieux connaître la place des légumineuses fourragères. L'expérience méditerranéenne. Fourrages 135, 289-310

Bellon S (1995) Stratégies sylvopastorales en région Méditerranéenne. Cahiers Opt méditer Sylvopastoral systems, 12 ,FAO-CHIEAM-INRA, 195-198

Benavides JE (ed) (1994) Arboles y arbustos forrajeros en America Central. Centro Agronomico Tropical de Investigacion y Ensenanza, CATIE, Serie Tecnica, Informe Tecnico, 236, 1-2, 721

Besse T, Sebillotte M (1986) Les fonctions des systèmes de culture au niveau de l'exploitation agricole; leur localisation dans le paysage. Proc workshop Systèmes de production à dominante céréalière dans le semi-aride, Jebel Oust, Tunisie, 231-261

Bullitta P, Bullitta S, Porqueddu C, Roggero PP (1992) Produzione di seme di trifoglio bianco (Trifolium repens $L$.) in un sistema integrato con l'allevamento di ovini da latte in Sardegna. In: Atti della Tavola Rotonda Sementi per le colture foraggere mediterranee, Sassari, 219-232

Bullitta P, Bullitta S, Roggero PP (1989) Agronomic methods to increase pastureland production in Mediterranean marginal areas. In: Proc XVIth Intern Grass Cong. Nice, France, 1591-1592

Bullitta $P$, Spanu A (1977) II ruolo dei cereali autunno vernini nell'approvvigionamento foraggero delle aziende meridionali. Studi Sassaresi, sez III, Annali della Facoltà di Agraria dell'Università di Sassari 25, 1-16

Caredda S, Porqueddu C, Roggero PP, Sanna A, Casu $S$ (1992) Feed resources and feed requirements in the sheep agro-pastoral system of Sardinia. In: Proc IVth Intern Rang Cong, Montpellier, France, 734-737

Casu S, Porqueddu C, Sanna A (1989) Aspetti produttivi e gestionali delle aziende zootecniche nella Comunità Montana Marghine-Planargia. In: Relazione finale a conclusione del Progetto Finalizzato IPRA CNR (Idda L, ed) sottoprogetto 2.2, area problema Sardegna, 159-250

Cereti CF, Talamucci P (1991) Possibilità di studio e di organizzazione del sistema foraggero pratopascolivo. Rivista di Agronomia 2, 148-169

Cocks PS, Gintzburger G (1993) Long-term sustainability of livestock producing farming systems in contrasting regions with mediterranean-type climates. In: Proc XVIIth Intern Grass Cong, New Zealand-Australia, 247252

Conway GR (1987) The properties of Agroecosystems. Agricultural Systems 24, 2, 95117

Delgado IE (1992) Extension ou intensification de la production fourragère dans le bassin méditerranéen. Herba 5, 25-30

Devendra C (1991) Potential integration of small ruminants with tree-cropping systems in Asia and the South Pacific. World Animal Review 66, 13-22

Devendra C (1993) Sustainable animal production from small farm systems in South-East Asia. In: FAO Animal Production and Health (Speedy $A_{\text {, }}$ Pugliese P, eds) Paper 106, $143 p$

Ewing MA (1989) The development of pasture legumes for the low rainfall cereal-livestock zone of southern Australia. In: Proc XVIth Intern Grassland Congs, Nice, France, 197-198

Farrington J, Nelson J (1991) Perspectives on sustainable agriculture and an economic view on sustainable agriculture. Work Paper, ODI, London, $10 \mathrm{p}$

Franca A, Porqueddu C, Roggero PP, Sulas L (1995) Adattamento e produttività di alcune graminacee da prato e da pascolo in ambiente semi-arido mediterraneo. Rivista di Agronomia 29, 2, 171177

Gradwohl J, Greenberg R (1988) Saving the Tropical Forests. Earthscan Public LTD, London, 1123-1125

Guerin G, Bellon S (1989) Analysis of the functions of pastoral areas in forage systems in the 
mediterranean region. Etud Rech Syst Agr Dév 16. INRA-SAD Paris, 147-156

Guérin G, Lardon S, Osty PL, Triboulet P (1994) Comprendre et représenter l'organisation spatiale des systèmes techniques. L'élevage ovin extensif du sud du Massif Central (Causse Méjan, France). In: Systems-Oriented Research in Agriculture and Rural Dev Int Symp, Montpellier (France), CIRAD-SAR (ed), 119-124

Guessous F, Rihani N, Kabbali A, Johnson WL (1989) Improving feeding systems for sheep in a Mediterranean rain-fed cereals/livestock area of Morocco. J Anim Sci 67, 3080-3086

Hardesty LH (1988) Multiple-use management in the Brazilian Caatinga. J Forest 35-37

Hubert B, Deverre C, Meuret M (1995) The know-how of livestock farmers and new objectives for European farming. In: Proc Vth Intern Range Cong Salt Lake City, USA, in press

INRA Ecodéveloppement, CERPAM (1990) Espaces forestiers, élevage et incendie. In: Revue Fores Fr (Delabraze $P$, ed), $n$ spécial, 156-172

ISTAT (1994) Statistiche dellagricoltura, zootecnia $e$ mezzi di produzione - anno 1992, Annuario 40, Roma

Jarrige R (1979) Utilisation des pâturages des milieux défavorisés: essai de conclusions. In: Utilisation par les ruminants des pâturages d'altitude et parcours méditerranéens, 10e journées du Grenier de Theix, INRA, Paris, 541-566

Jean B (1995) S'approprier le développement: le développement local et le développement durable comme formes de développement approprié. in. L'éthique de développement; entre l'ephémère et le durable, GRIR, Col Dév Rég, Univ Québec Chicoutimi, 299-320

Langlet A, Flamant JC, Molenat G, Osty PL (1979) Les parcours des grands Causses: contraintes et possibilités techniques d'une mise en valeur par l'élevage ovin. In: Utilisation par les ruminants des pâturages d'altitude et parcours méditerranéens, 10e journées du Grenier de Theix. INRA, Paris, 257-335

Mejia CE, Rosales M, Vargas JE, Murgueitio E (1991) Intensive production from African hair sheep fed sugar cane tops, multinutritional blocks and tree foliage. Livestock Res Rural Dev 3, 1, 53-58

Meuret M (1993) Piloter l'ingestion au pâturage. In Pratiques d'élevage extensif. Identifier, modéliser, évaluer (2ème éd) (Landais $E$, ed) INRA Etud Rech Syst Agr Dév, 27, $380 p$

Meuret M, Bellon S, Guérin G, Hanus G (1995) Pảturer sur parcours. 2éme Renc Rech Rum INRA-IE, Paris, 27-36

Molle G, Spanu E, Ligios S, Vargiu M, Arangino R, Casu $S$ (1994) Effect of partial irrigation on performances of dairy sheep grazing $90 \%$ of native pastures buffered by $10 \%$ of sown forages.
In: Proc Intern Symp Optimal expl marg mediter areas by extens rumi product syst, Thessaloniki, Greece, $50 p$

Moog FA (1992a) Heteropsylla cubana: impact on feeding systems in the southwest Asia and the Pacific. In: Legume trees and other fodder trees as protein source for livestock (Speedy A, Pugliese $P$, eds) FAO Anim Product and Health Paper 102, 1-10

Moog FA (1992b) The role of fodder trees in Philippine smallholder farms. In: Legume trees and other fodder trees as protein source for livestock (Speedy A, Pugliese P, eds) FAO Anim Product and Health Paper 102, 193-209

Moog FA, Sison JP (1986) Impact of the ipil-ipil psyllid infestation in the animal Industry. Bureau of Animal Industry, Quezon City, Philippines (mimeographed) $12 \mathrm{p}$

NFTA (1987) Proceedings of a workshop on biological and genetic control strategies for the Leucaena psyllid. A special edition of Leucaena Research Reports. Honolulu. 7, 2

Ocampo A (1995) The African palm: a strategic resource for integrated systems of tropical production. In: Proc the first Electron Conf Trop Feeds and Feeding syst. FAO Feed Resource Group and Animal Production and Health Division. On-Line Proceedings by: Speedy AW, Internet address:HTTP://ifs. plants.ox.ac.uk/fao/tropfeed/co nsult.htm.

Pirisi A, Piredda G, Molle G, Ligios S (1994) Effetto di differenti sistemi di allevamento della pecora da latte sulle caratteristiche del latte e dei prodotti caseari. Atti del XLVIII convegno SISVET, Giardini Naxos, 209

Pluvinage $\mathrm{J}$ (1995) Les systemes de production céréales-élevage et la gestion du risque dans les zones sèches méditerranéennes. PhD Thesis, ENSAM , $377 p+$ Appendix

Preston TR (1992) The role of multi-purpose trees in integrated farming systems for the Tropics. In: Legume trees and other fodder trees as protein source for livestock (Speedy A, Pugliese P, eds) FAO Animal Production and Health, Paper, 102, 193-209

Preston TR, Murgueitio E (1992a) Strategy for Sustainable Livestock Production in the Tropics. CIPAV-SAREC. Condrit LTD. Cali, Colombia. $89 \mathrm{p}$

Preston TR, Murgueitio E (1992b) Sustainable intensive livestock systems for the humid Tropics. World Anim Rev, 3, 2-8

Pretty JN, Howes R (1993) Sustainable agriculture in Britain; recent achievements and new policy challenges. In: Res Series Sustain Agric Prog. Intern Inst Env Dev, London, 2, 74 p

Ravnorg (1992) Farmers as soil resource managers. In: La recherche développement pour une agriculture durable/écologique. Atelier du GRET, réseau $\mathrm{A} / \mathrm{D}$, Paris 
Reeves TG, Ewing MA (1993) Is ley farming in the Mediterranean zone just a passing phase? $/ \mathrm{n}$ : Proc XVIIth Intern Grass Cong. New ZealandAustralia, 2169-2177

Robson AD (1990) The role of self-regenerating pasture in rotation with cereals in Mediterranean areas. In:The role of legumes in the farming systems of the Mediterranean areas.(Osman AE, Ibrahim MH, Jones MA, eds) Proc of a UNDP/ICARDA workshop, Tunis, Developments in plant and soil sciences, Kluwer Academic Publishers, The Netherlands, 38, 217-236

Roggero PP, Franca A, Sitzia M, Caredda S (1993) Canopy structure and forage production of Lolium rigidum Gaudin as influenced by the frequency of defoliation. In: Proc the XVIIth Intern Grass Cong, New Zealand-Australia, 168-170

Roggero PP, Porqueddu C, Bullitta S, Veronesi $F$ (1990) The choice of suitable species and varieties for the rainfed Sardinian forage systems. In: Proc 6th Meet FAO Sub-network on Mediterranean pastures and fodder crops, Bari, 77-81

Röling NG (1992) Facilitating sustainable agriculture: turning policy models upside down. Proc Beyond farmers first: rural people's knowledge, agricultural research and extension practice. Brighton (UK), Inst Dev Stud, Univ Sussex

Rosales M, Preston TR, Vargas JE (1992) Advances in the characterization of non conventional resources with potential use in animal production. In: Proc Anim Product Dev Countries. Br Soc Anim Product. Occasional Publication, 16, 228-229

Rubino R, Moioli B, Fedele V, Pizzillo M, Morand-Fehr $P$ (1995) Milk production of goats grazing native pasture under different supplementation regimes in southern Italy. Small Rumin Res 17, 213-221

Scoones I (1989) Patch use by cattle in dryland Zimbabwe: farmer knowledge and ecological theory. Proc workshop on Socio-economic determinants of livestock production in Zimbabwe's communal areas, Masvingo (Zimbabwe). ODI Pastoral Development Network, $28 \mathrm{~b}, 30 \mathrm{p}$

Spedding CRW (1995) Sustainability in animal production systems. Anim Sci 61, 1-8

Stergios B (1995) First Census Completed in Venezuela's Western Llanos. SI/MAB Biodiversity News. Smithsonian MAB Program. Spring/Summer, 4, $17 p$

Sulas L, Porqueddu C, Caredda S, Bullitta P (1993) Use of annual legumes for pasture improvement in Mediterranean environment. Proc 7 th Meeting of the FAO sub-network on Mediterranean pastures and fodder crops Management of Mediterranean shrublands and related forage resources, Chania, Greece, FAO REUR technical series 28, 32-35

Sulas L, Porqueddu C, Roggero PP, Bullitta P (1994) Comparison between rainfed forage systems for dairy sheep in Mediterranean environment. In: Proc 3rd Eur Soc Agron Cong, Abano-Padova, 748-749

UICN (World Conservation Union), UNEP (United Nations Environment Programme), and WWF (World Wide Fund for Nature) (1991) Caring for the Earth. A strategy for Sustainable Living. Gland, Switzerland, $228 \mathrm{p}$

World Resources Institute (WRI) (1990) World Resources 1990-1991. Intern Inst Env Dev, Oxford Univ Press. Oxford, 93-95 